\title{
An Analysis of Sociogenesis Motive of Main Character in "Unbroken" Movie
}

\author{
Juwita Boneka Sinaga \\ English Education Department \\ University of Riau Kepulauan \\ juwitaboneka@gmail.com
}

\begin{abstract}
This research entitled "An Analysis of Sociogenesis Motive of Main Character in 'Unbroken' movie. It discussed the socio genesis of the main character in the movie "UNBROKEN", Unbroken movie which released in 2014 American biographical thriller film in sydney, Australia. This research analyzed the sociogenesis motives of Louis that reflected in "Unbroken" movie. This research applied a qualitative research method. Data collection procedures was got by watching the movie repeatedly, took important data, arranged the data, looked for supporting data and arranged the data sistematically. The method which was used by the writers in analyzing the conflict of the main character in this movie was a descriptive qualitative method.. Data analysis procedures was analyzed by using the quotation of the film. Primary data source was Unbroken movie. While secondary data sources were collected from many sources such as the articles, script of movie, biography of the author, journal from internet, and books related to this research as references to support the data found. Based on the result of analysis, the answer to question was as follows. Louis's sociogenesis motives was sociogenesis motive with the natural condition of life (drowning, huge waves, strong wind, scorching sun, shortage of food), sociogenesis motives with other species (shark's attack) and sociogenesis motives with members of one's own species (contumely from watanabe, the bird). It was concluded that Louis is a man that had incredible sociogenesis motive to survive with the difficult situation. In this research, the writer described how the personal conflict of the main character in the movie "Unbroken" was.
\end{abstract}

Keyword : sociogenesis, motive, movie

\section{INTRODUCTION}

This research was done based on the abstract of the conflict analyzing on the main character in the movie "Unbroken". Generally movie has a meaning that director given to the people that watch the movie, the director want people to understand the meaning of the movie these made by director, because movie can contained educative or persuasive information, those mean movie can give new knowledge to the people that can get from the meaning of the movie, because the meaning of the movie can be shown by the sign of some actors, some 
action or body language or by the personality of the main character in the movie, and also movie not just appreciate a beautiful or handsome actor, or good action that show by the actor, but a movie always gives meaning want to be appreciated that presented in the movie to provide inner satisfaction for the audience.

Therefore the writer appreciated her favorite movie of all time is "UNBROKEN", not only it is a good story and a nice movie ever made, but because this movie taught us a lot feeling of someone and the knowledge of this life. All the ideas, messages or any event can already be created and displayed by using audiovisual technology. Even the fact things around humans (documentative) and the fiction from imagination. The film could give the impression more dramatic than the real event. The special reason why people like a movie because there is element in human's efforts to find entertainment and take the time, because the film looks lively and interesting. In literature work especially film, there is character to support film itself.

Luois' sociogenesis motives are begun in the Pacific Ocean, with their modest food supplies to survive in the middle of large ocean. Many events that examine Louis' sociogenesis motives and his two friends. Starting from the starvation because the food supplies that are spent by Mac. Consequently, they have to eat the raw foods such as uncooked birds, raw fish and raw shark. Not only that, Louis also had to survive to confront the extreme weather and climate and also survived from the attack of the shark .In addition to survive in the middle of the Pacific Ocean, Louis also has to sociogenesis motive to survive from as a prisoner of Japan for two years. This condition happened when they were in the middle of the sea especially on day 47. Louis and Phill were captured by the Japanese army and sent them to the Omori camp. Louis and Phill then are separated. Louis met Watanabe when Louis stay at Omori camp. Watanabe is the most sadistic corporal in Omori camp that usually called "the bird."

Louis fought and survived with all the sadistic attitudes shown by Watanabe him. Watanabe did not like Louis because Louis is the only person who dared to oppose it by looking at his eyes. Not only that, Watanabe also hated Louis because Louis also has a carrier as a famous athlete. It makes Watanabe becomes dislike Louis. Many actions that are conducted by Watanabe to make Louis admits Watanabe's power, for example Watanabe gives a command for 220 prisoners to hit the Louis'face. Louis received 220 punches until he was fainted, but Louis still never give up. He always showed the unyielding attitude to Watanabe. Finally, Louis can pass all difficulties to survive until the World War 2 has paid off. It makes Louis can return to America and met his family. The incident made Louis 
becomes trauma and alcoholic. But Louis kept his words to serve the Lord if he can survive from the terrible incident.

Here the researcher wanted to reveal about the Louis' character sociogenesis motives. How hard he tried to survive with his friends. Louis tried to save himself from many difficult situation. Therefore, the researcher wanted to know deeper about Louis sociogenesis motives to save his life from difficult situation, the researcher used Charles Darwin's theory about sociogenesis motive for existence. There are three types of sociogenesis motives for existence such as sociogenesis motives with natural condition of life, sociogenesis motives with other species and sociogenesis motive with member of one's own species. The objective of the research was to answer the questions as mention in the problem of the research was to analyze the main character's sociogenesis motives.

\section{Conflict}

Basically, rise of conflict because of social interests of certain groups or because of individuals who have a personal interest. Conflicts can happen because human needs that are unmet. Unmet needs can form the unhealthy personal. In this conditions occur restraint on feelings of self-actualization and deliberate a process of discrimination from the environment.

Meanwhile, according to Laurence Perrine (1988) in Saputra, (2010:48), conflicts is a clash action, desires, ideas, or goals in the plot of a story or drama. Conflict may exist between the main character and other person or persons (man again man): between the main character and some external force physical nature, society, or fate (man against some destructive element in his own nature (man again himself).

\section{Personal Conflict}

According to Rakhmat (2002:33-34), personal conflict is perspective centered on issues that question the personal factor, either in the form of attitudes, instincts, motives, personality, cognitive systems that human explain the behavior. Therefore personal conflict comes from the personality of the human. Generally, the personal conflict has two kinds those are: Biological Factor and Socio-psychological Factor.

\section{1) Biological Factors}

According to Rakhmat (2002:34), the biological factor is factors involved in all organism activity. Human is biological being that is not different with another animal. Biological factor can be determined by human behavior, this begins from the structure of the DNA that human stores in the memory of human biological 
inheritance received from both parents. Example instinct and sexual motive, feeding, treat children, aggressive behavior.

\section{2) Socio-psychological Factors}

According to Rakhmat (2002:37), human is a social being, therefore social process human obtained some of the characteristics that influence several characterizations that influence behavior, according to Rahmat Socio-psychological factor classified in three components those are, Affective component, Conative Component, and Cognitive Component.

The first component in Socio-psychological Factor is Affective Component. This component can be called as the emotional aspect of Socio-psychological Factors such as happy, angry, hate, agree, revenge, and disappointment. Affective Component are influenced by three motives those are: Socio-genesis Motives, Attitude Motives, Emotion Motives.

\section{Socio-genesis Motives.}

According to Rakhmat (2002:37), this motive often called as the secondary motive as the opponent of primer motive (biological motive). Socio-genesis as a motive can be learned by human and coming from the cultural environment of human stay and progress. The part of socio-genesis motive in form social behavior very decide.

\section{Curiosity Motives}

Curiosity is trying to understand, organize and predictability. Every human try to obtain the meaning of his world.

\section{Competence Motives}

Human wants to prove that someone has the ability to solve the problem. The ability is a certainly in solving the problem in this life to obtain a safe life and beautiful life.

\section{Love Motives}

Human can be able to love and be loved essential for the growth of personality. The warmth of friendship, sincerity love, acceptance of others warm indispensable human.

\section{Pride and Looking for Identity Motives}

Pride and looking for identity means that Human Needs to show his existence in the world.

\section{Valuable, Longing and Meaning of Life Motives}

When human solves the problems in his life, human need the values to guide them in making decision or giving a meaning of his life. The value that means the knowledge of someone to something that human felt true or not related to his purpose of life. 


\section{Self-Actualization Needs}

Human not only want to maintain of his life, human also wants to fulfill his potential. Self-actualization can be called as the process of using the potential of a person or situation that resulting.

\section{METHODOLOGY}

The research design is all the processes which are needed in planning and doing a research. In this research the writers used descriptive method to analyze the data. The object of this analysis was the main character in the movie "Unbroken" is Descriptive method according to Arikunto (2007) in Dermawan (2013:01) to solve a problem or answer the problem faced with collecting the data, clarify, analyze, process, make a conclusion and report. Data sources refer to certain movie, in the library, book, journal and many others from in which the data are taken. The data source in this study is the movie "Unbroken" director by Angelina Jolie. This research consisted of two data source such as primary data source and secondary data source. According to Hox and Boeiji (2005:593), Primary data are data collected for the specific research problem at hand, using procedures that fit the research problem best. Based on the statement above primary data is the first data and researcher get the data without the mediator. The primary data sources in the research is the movie itself Unbroken movie ssecondary data sources. According to Hox and Boeiji (2005:593), Secondary data is created by other researcher is made available for reuse by the general researcher community. The secondary data sources consist of the data, which have relationship with the study, such as other relevant information. It means secondary data has benefit to enrich, increase the analysis from journal, magazine, and creation of literary, article, internet, book, and reference which are relevant with this study. Thus, secondary data is the data get from through mediator. The secondary data were taken from the other sources which are related to the primary data such as script of the movie and the biography of the author.

\section{RESULTS}

The conflict on the main character in the movie "Unbroken" based on Rakhmat Theories especially on socio-genesis motives. the writer in analyzing the personal conflict of 
the main character named Christoper MC andless in the movie "Unbroken". The analysis focused on the struggle of main character.

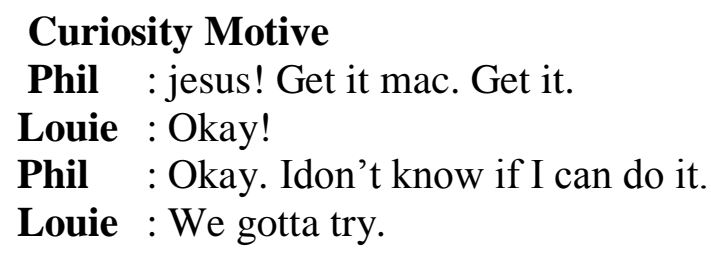

(Unbroken, 2014: 00:40:38 - 00:41:15)

From the data above, after the problem of chocolate and drinking, Louis stares up in the sky and suddenly come a bird that landed on their raft precisely beside Louis. Phill and Louis looked each other and at the moment Louis capturing the bird quickly, after that they cut the bird by the mirror that he hold and eat the bird. Hence, they spew the raw bird and find another idea to survive.

After catching and eating the bird, Louis find another idea to survive, he tries to fishing. Not unexpectedly they obtain the fish. This condition can be seen from the following quotation.

\section{Competence Motive}

Louie : Did you see that Mac surprise attack? He came down on that thing like a Goddamn dive bomber. Damn sharks were scared shit.

Phil : Saved your skinny ass.

(Unbroken, 2014: 00:55: 37 - 00:55:51)

Based on the first quotation above, there is a shark attack on Louis, but Mac save him by hitting the shark by the paddle. Louis asks to Phill "did you see the mac surprise attack?". And then Phil says to Louis that Mac save his back of the body. Louis and Phill surprised because Mac save Louis's life and thanks to Mac.

In the middle of ocean is likely we will face the threat of another species. Louis survive with other species like shark (predator) by Mac's help. This condition is very suitable with Darwin's statement that is human's battle with other species upon whom they prey and who prey upon them (Darwin).

\section{Love Motive}

Watanabe : Stand up! Stand up! Pick up! Lift high. Over your head. You stand! You stand with this! Lift high! If he drops it, shoot him. (a few minutes later) don't look at me.

(Unbroken, 2014: 01:54:23 - :01:59:39) 
Based on the quotation above, Watanabe orders to Louie to lift the big wooden on his head, and he say to the guards if Louis drops it shoot him. Louie does that. In minutes later Louis look at him and lift the big wooden and screaming loudly to the Watanabe. After that Watanabe feel lose because Louis stare up at him sharply, and the spirit of Louis unbroken. He hit Louis brutally and heatedly. But Louis keep survived.

\section{DISCUSSION}

"Unbroken" Movie is a movie told that there are many types of socio-genesis motive that found by the writers. They were described below:

1. Curiosity Motive described by the main character who tries to understand, organize and predictability his identity and something in his life.

2. Competence Motive described by the main character who solving the feeling of anxieties and wants to get the beautiful life.

3. Love Motive described by the main character who has a good relationship with others, accepted in his environment and felt lonely in the wild.

4. Pride and Looking for Identity Motive described by the main character who measured himself as aesthetic voyager, extremist and looking for his true identity in the wild.

5. Valuable, Longing and Meaning of Life Motive described by the main character who gave the value about the meaning of love and the meaning of this life.

6. Self-actualization Needs described by the main character who wants to find the truth, simplicity, aliveness, depend on his self and looking for absolute freedom.

\section{REFERENCES}

Darmawan, Ahmad. (2013). Analisis karakter tokoh dan alur dalam novel pengembaraan Hang Jebat pencarian merentas zaman karya Ashadi Zain dan Moh Dat Molok". Tanjung.

Hox, Joop and Henie Boejie. (2005). Data collection, primary vs secondary. Encyclopedia of Social Measurement 1:593.

Rakhmat, Jalaludin. (2002). Psikologi komunikasi. Bandung: Remaja Rosdakarya.

Saputra, Ignatius Andi. (2010). Ambisi tokoh Frank Lucas dalam script film American Gangster. Semarang: Universitas Diponegoro. 